\title{
Comparative Study of Microcalorimetric Behavior of Escherichia coli, Proteus mirabilis and Klebsiella pneumoniae
}

\author{
NATIVIDAD LAGO RIVERO ${ }^{1 *}$, JOSÉ L. LEGIDO ${ }^{2}$, ISAAC ARIAS SANTOS ${ }^{1}$ and LIDIA M. CASÁS² \\ ${ }^{1}$ Pharmacy Service, University of Vigo Hospital Complex (Xeral-Cíes), Vigo (Pontevedra), Spain \\ ${ }^{2}$ Department of Applied Physics, Faculty of Science, University of Vigo Campus (Lagoas Marcosende), \\ Vigo (Pontevedra), Spain
}

Received 11 October 2011, revised 28 January 2012, accepted 1 July 2012

\begin{abstract}
To analyze the microcalorimetric behaviour of Escherichia coli, Proteus mirabilis and Klebsiella pneumoniae, and to test the prospective use of microcalorimetry in the early diagnosis of infections by enterobacteria. For our experiments we used cultures of E. coli, P. mirabilis and K. pneumoniae. For the experimental setup, we used a Calvet microcalorimeter with the constant temperature of $309 \mathrm{~K}$ inside. Using the measured difference of heat power generated by the cells over time, we obtained growth graphs of the three bacterial species grown at different densities. The generated curves have characteristic plot that repeats for each bacterial species at all the concentrations studied. We observed an inversely proportional relationship between inoculum size and the time until signal detection; the smaller inoculum, the longer time for the signal detection. In all conducted experiments, even with low number of bacteria $(10 \mathrm{CFU} / \mathrm{ml})$ as inoculum, we could identify bacterial growth in the sample within 8 hours. Microcalorimetry could be an efficient technique used for the early detection and identification of enterobacteria in a culture medium.
\end{abstract}

Ke y words: Enterobacteria, diagnosis of microbial infection, microcalorimetry, thermogram

\section{Introduction}

The enterobacteriaceae are a relatively homogeneous group within the gammaproteobacteria. The group is composed of rod-shaped gram-negative, facultative anaerobes, which are either immobile or are motile using peritrichous flagella (Murray et al., 2009).

Another important taxonomic feature that differentiates the various genres of enterobacteria is the type and proportion of glucose fermentation by-products. We can distinguish two broad profiles: mixed-acid fermentation and butanodiol fermentation. Mixed-acid fermentation generates three acids in significant amounts: acetic, lactic and succinic; and to a lesser extent ethanol, $\mathrm{CO}_{2}$ and $\mathrm{H}_{2}$, but not butanodiol. Butanodiol fermentation, on the other hand, produces fewer acids, while the main products are butanediol, ethanol, $\mathrm{CO}_{2}$ and $\mathrm{H}_{2}$.

Enterobacteriaceae are ubiquitous organisms, which are universally found in soil, water, vegetation, and in the normal intestinal flora of many animals, including humans. They produce a wide variety of diseases in humans, between $30-35 \%$ of the bacteriaemias, more than $70 \%$ of urinary tract infections (UTI) and many intestinal infections. Some microorganisms are associated with disease in humans, while others (e.g. Escherichia coli, Klebsiella pneumoniae, Proteus mirabilis) are part of the normal commensal micro-flora and can cause opportunistic infections (Kenneth et al., 2004).

Microcalorimetry is an experimental technique that allows us to precisely measure the energy released by a process or transformation (Calvet and Prat, 1956).

This technique has potential to be used in biological experiments, since heat flow is strongly related to the kinetics and thermodynamics of biological processes. Heat variations resulting from chemical reactions, which take place during metabolism, can be used to monitor bacterial growth, and monitor the influence of external agents (Ma et al., 2007; James, 1987).

All living organisms produce heat during their metabolism. The rate of heat production is an adequate measure of the metabolic activity of the organisms and their constituent parts, cells and sub-cellular levels (Trampuz et al., 2007). The heat generated by a single cell is in the range of $1-80 \mathrm{pW}$. Human connective tissue cells (fibroblasts, adipocytes) have metabolic rates of approximately $25-80 \mathrm{pW}$ per cell. In contrast,

\footnotetext{
* Corresponding autor: N.L. Rivero, Pharmacy Service. University of Vigo Hospital Complex (Xeral-Cíes). C/Pizarro nº 22, 36202, Vigo (Pontevedra), Spain; phone: (+34) 986816007; fax: (+34: 986816089; e-mail: natividad.lago.rivero@sergas.es
} 
microorganisms produce small amounts of heat, about $1-3 \mathrm{pW}$ per cell. Despite the low levels of heat produced by the bacteria, their exponential growth in culture medium allows their detection using microcalorimetry within a few hours, even with the starting inoculum as low as $10 \mathrm{CFU} / \mathrm{ml}$.

Microcalorimetry is used in biology, pharmacology, biotechnology and ecology due to its high sensitivity, precision and simplicity. However, its use in clinical analysis has remains highly limited. In microbiological research, calorimetry seems to be particularly valuable since it allows to record rapid metabolic changes and the speed and effectiveness of the growth in the presence of different agents (O'Neill et al., 2003; Wang et al., 2005; Liang et al., 2003; Yang et al., 2010; Xu et al., 2008). It also allows detection of changes in culture properties in real time.

Despite available recent literature, the microcalorimetric investigation of bacterial growth is still almost not studied. Given the sensitivity of the technique and the rapid results, we can postulate that microcalorimetry is a technique with great potential to be developed in clinical practice.

The objective of this work is to analyze the microcalorimetric behaviour of E.coli, P. mirabilis and K. pneumoniae, in order to study the contribution of microcalorymetric technique in the early diagnosis of infections by enterobacteria.

\section{Experimental}

\section{Material and Methods}

Sample preparation. For all our experiments we used strains purchased from the American Type Culture Collection (ATCC) and Spanish Type Culture Collection(CECT): E. coli (ATCC 25922), P. mirabilis (CECT 170) and K. pneumoniae (CECT 144).

Bacteria were grown on blood agar plates and incubated at $310.15 \mathrm{~K}$ in an incubator for 24 hours. Bacteria scraped from plates were mixed with $0.9 \%$ saline solution, bacterial density was adjusted to 0.5 on the McFarland scale. This bacterial suspension was then used to prepare inocula of final concentrations $10^{6}$, $10^{5}, 10^{3}$ and $10 \mathrm{CFU} / \mathrm{ml}$ (Lago et al., 2010a; Lago et al., 2010b). The culture medium consisted of a liquid enriched with digested soy-casein.

Experimental equipment. The measurements were taken by the Calvet microcalorimeter equipped with aluminium and Teflon cells of $10 \mathrm{ml}$ capacity and a device allowing operation in the absence of vapour phase (Calvet and Prat, 1956). A Philips PM2535 Multimeter and a data collection system were coupled to the microcalorimeter. Calibration was done electrically using the EJP30 Setaram stabilised current source. The

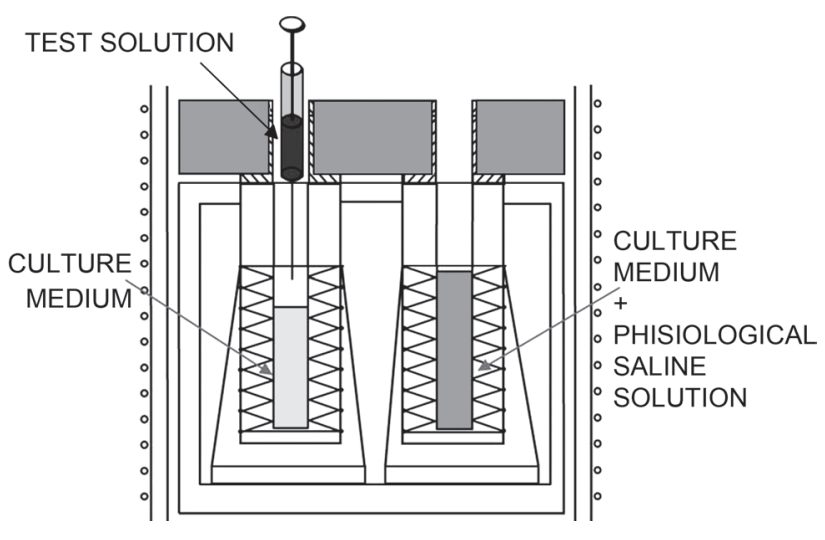

Fig. 1. Diagram showing the microcalorimeter cells

precision of calorimetric signal was $\pm 1 \mu \mathrm{W}$. Further details about the experimental method have been published previously (Paz Andrade, 1967).

Experimental setup and data collection. The external environment of the calorimeter was maintained at a constant temperature of $309.65 \mathrm{~K}$. The reference cell was injected with $7 \mathrm{ml}$ of culture medium $+1 \mathrm{ml}$ of saline without bacteria (control), while the experimental cell was injected with $7 \mathrm{ml}$ of culture medium (Fig. 1). Both cells were then inserted through two cylindrical holes, which extended from the upper part of the microcalorimeter to the internal chamber. The large distance that separates the cells from the entrance allows minimisation of heat flow to the exterior. The system was left to stabilise for about two hours, after which $1 \mathrm{ml}$ of the bacterial culture of known density was introduced into the experimental cell (Lago et al., 2010 b). All experiments were repeated in triplicate.

Data was collected using the data collection and processing system, at 15 seconds intervals throughout the duration of the whole experiment.

Because bacteria produces metabolic byproduct which modify the $\mathrm{pH}$ of the medium, samples were subject to a $\mathrm{pH}$ control both before and after each experiment using a basic $20+\mathrm{pH}$ meter.

\section{Results}

Using the experimental difference of heat power generated by the cells over time, we obtained growth graphs of the three enterobacteria at different concentrations. We could identify the different stages of bacterial growth: lag, log, stationary and death phases.

The curves generated during the experiment have a characteristic form that repeats for each bacteria species at all the concentrations studied (Figs. 2-4). Furthermore, we observed an inversely proportional relationship between inoculum size and the time until signal detection; the highest density of bacteria, the earlier signal is detected. In any case, even at low bacterial 


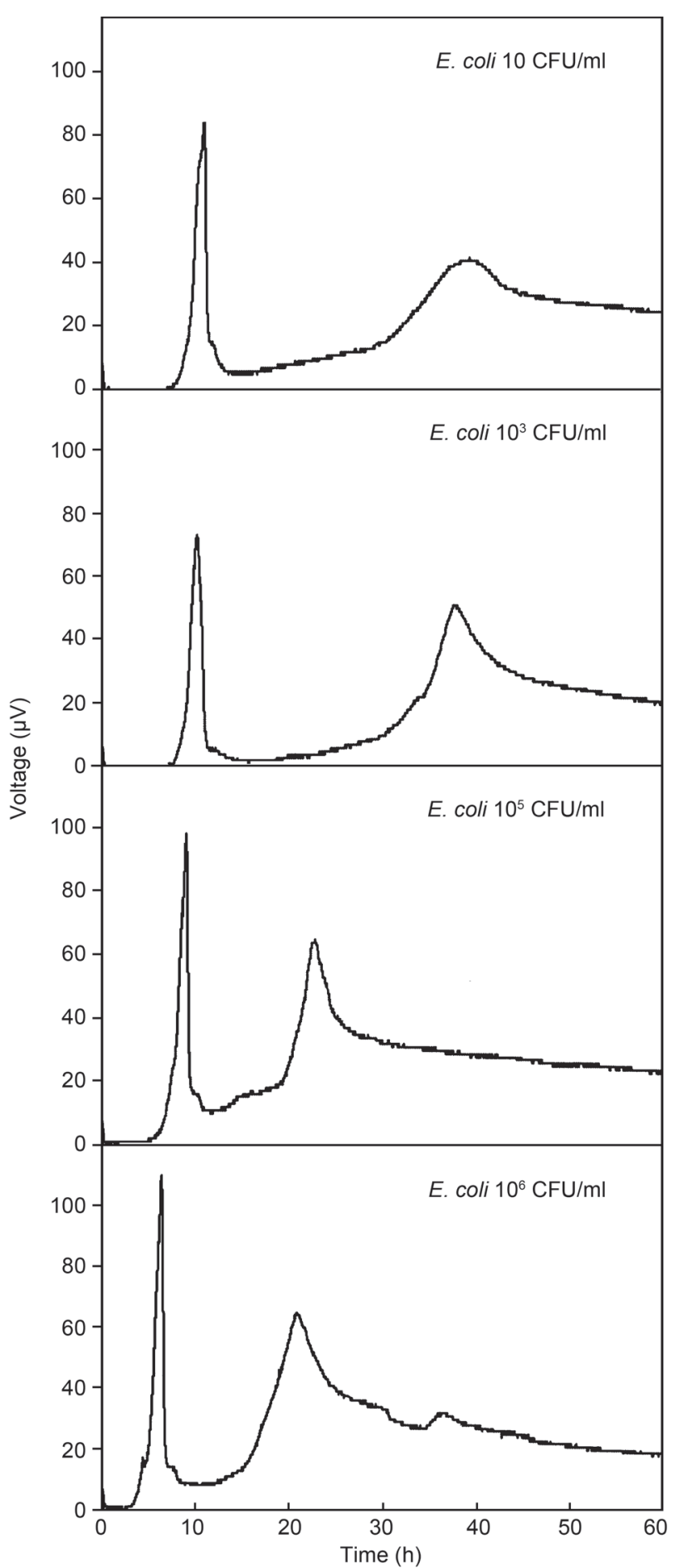

Fig. 2. Calorimetric signal v/s time for the E. coli at the different studied concentrations: $10^{6}, 10^{5}, 10^{3}$ and $10 \mathrm{CFU} / \mathrm{ml}$

density $(10 \mathrm{CFU} / \mathrm{ml})$, we can identify bacterial growth in the sample within 8 hours. The appearance of the highest peaks is related to bacterial concentration, and although at high bacterial densities the peaks are more intense, we cannot establish a relationship of proportionality (Tables I-III).

As mentioned earlier, one of the taxonomic features of the enterobacteria is the type of glucose fermentation, and in this sense, E.coli and P. mirabilis

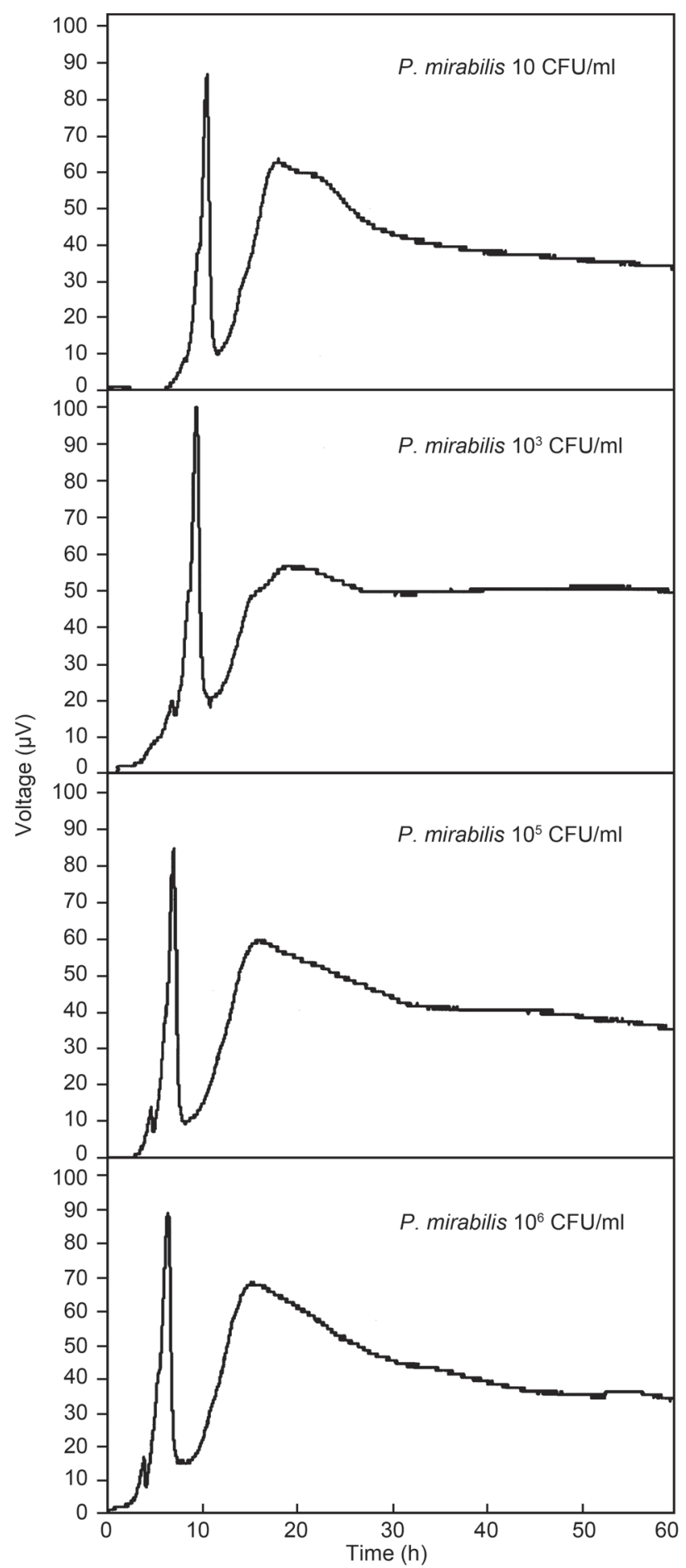

Fig. 3. Calorimetric signal v/s time for the P. mirabilis at the different studied concentrations: $10^{6}, 10^{5}, 10^{3}$ and $10 \mathrm{CFU} / \mathrm{ml}$

show mixed-acid fermentation, while K. pneumoniae is characterized by butanodiol fermentation. This could explain the differences and similarities that we observe in the thermograms we obtained.

In the case of E. coli and P. mirabilis we observe two metabolic phases, the first with greater energy, but shorter duration, followed by a period of latency that precedes a second period of lower energy that is prolonged over time. The main difference between 


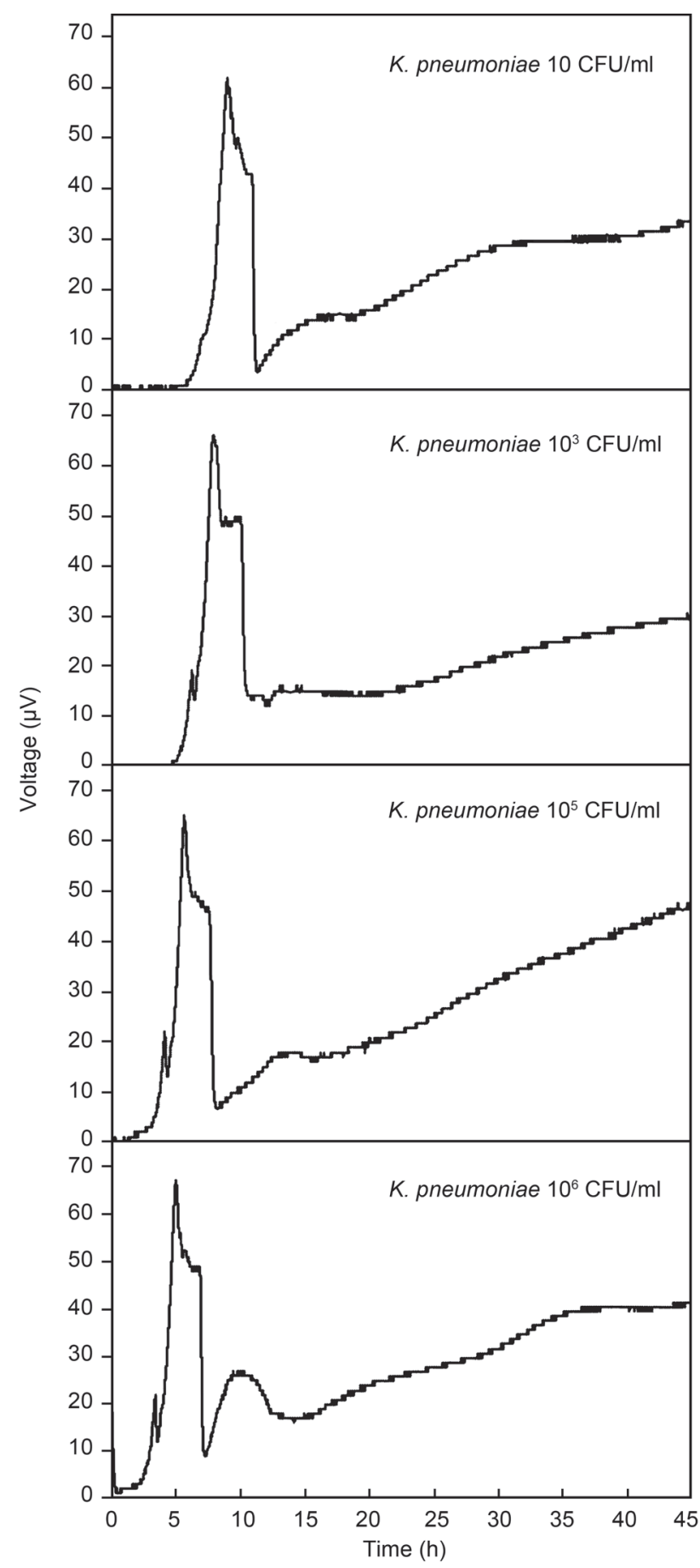

Fig. 4. Calorimetric signal v/s time for the K. pneumoniae at the different studied concentrations: $10^{6}, 10^{5}, 10^{3}$ and $10 \mathrm{CFU} / \mathrm{ml}$

the profiles of these bacteria is the time between the two peaks of flow. In case of E. coli, this period is longer. In the case of P. mirabilis, after the first characteristic peak in all the thermograms, and before the first peak of maximum voltage, we observe an area without peaks, but which can be described using a polynomial type equation from which we are able to extract an inflexion point.

As for the thermogram of K. pneumoniae, it is clearly different from the other tested bacteria. In this case,
Table I

Time from start of the experiment to signal detection (td), maximum voltage peaks $\left(V_{p 1}, V_{p 2}\right)$ and registration time $\left(t_{p 1}, t_{p 2}\right)$ for E. coli

\begin{tabular}{|c|c|c|c|c|c|}
\hline $\begin{array}{c}\text { Conc. } \\
(\mathrm{CFU} / \mathrm{ml})\end{array}$ & $\begin{array}{c}t_{d} \\
(\mathrm{~h})\end{array}$ & $\begin{array}{c}t_{p l} \\
(\mathrm{~h})\end{array}$ & $\begin{array}{c}V_{p l} \\
(\mu \mathrm{V})\end{array}$ & $\begin{array}{c}t_{p 2} \\
(\mathrm{~h})\end{array}$ & $\begin{array}{c}V_{p 2} \\
(\mu \mathrm{V})\end{array}$ \\
\hline $10^{6}$ & 1.89 & 6.37 & 110 & 20.86 & 65 \\
\hline $10^{5}$ & 3.03 & 9.02 & 98 & 22.66 & 64 \\
\hline $10^{3}$ & 7.21 & 10.18 & 73 & 37.77 & 51 \\
\hline 10 & 7.56 & 10.94 & 84 & 39.10 & 42 \\
\hline
\end{tabular}

Table II

Time from start of the experiment to signal detection (td), maximum voltage peaks $\left(V_{p 1}, V_{p 2}\right)$ and registration time $\left(t_{p 1}, t_{p 2}\right)$ for $P$. mirabilis

\begin{tabular}{|c|c|c|c|c|c|}
\hline $\begin{array}{c}\text { Conc. } \\
(\mathrm{CFU} / \mathrm{ml})\end{array}$ & $\begin{array}{c}t_{d} \\
(\mathrm{~h})\end{array}$ & $\begin{array}{c}t_{p l} \\
(\mathrm{~h})\end{array}$ & $\begin{array}{c}V_{p l} \\
(\mu \mathrm{V})\end{array}$ & $\begin{array}{c}t_{p 2} \\
(\mathrm{~h})\end{array}$ & $\begin{array}{c}V_{p 2} \\
(\mu \mathrm{V})\end{array}$ \\
\hline $10^{6}$ & 1.68 & 6.39 & 88 & 15.65 & 69 \\
\hline $10^{5}$ & 3.11 & 7.01 & 85 & 16.15 & 60 \\
\hline $10^{3}$ & 3.18 & 9.46 & 99 & 19.49 & 57 \\
\hline 10 & 6.22 & 10.56 & 87 & 18.1 & 64 \\
\hline
\end{tabular}

Table III

Time from start of the experiment to signal detection $(\mathrm{td})$, maximum voltage peak $\left(V_{p}\right)$ and registration time $\left(t_{p}\right)$ for K. pneumoniae

\begin{tabular}{|l|c|c|c|}
\hline $\begin{array}{c}\text { Conc. } \\
(\mathrm{CFU} / \mathrm{ml})\end{array}$ & $\begin{array}{c}t_{d} \\
(\mathrm{~h})\end{array}$ & $\begin{array}{c}t_{p l} \\
(\mathrm{~h})\end{array}$ & $\begin{array}{c}V_{p} \\
(\mu \mathrm{V})\end{array}$ \\
\hline $10^{6}$ & 1.55 & 4.97 & 67 \\
\hline $10^{5}$ & 2.38 & 5.69 & 65 \\
\hline $10^{3}$ & 4.86 & 7.98 & 66 \\
\hline 10 & 5.65 & 8.98 & 62 \\
\hline
\end{tabular}

there is a characteristic phase in which, after the maximum peak, we observe a plateau after a sharp decline to very low levels around $10 \mu \mathrm{V}$. After this point, we see an exponential increase in heat flow, without this reaching a peak during incubation.

We fitted the curve to exponential and polynomial equations. In the logarithmic phase of the growth curve, we adjusted the data to an exponential equation. At this stage of the growth curve, microbial proliferation can be expressed as:

$$
n_{t}=n_{0} e^{k t}
$$

where $n_{o}$ is the number of cells at onset, $n_{t}$ the number of cells at time $\mathrm{t}$, and $\mathrm{k}$ the growth constant (Ma et al., 2007).

If $P w$ is the energy released by each cell, then:

$$
n_{t} P_{w}=n_{0} P_{w} e^{k t}
$$

Taking into account that the energy released at onset is $P_{0}$ and $P_{t}$ at time t:

$$
P_{t}=P_{0} e^{t}
$$


$\ln P_{t}=\ln P_{0}+k t$

The generation time $(\mathrm{G})$ is defined as the time needed by a population to double in size, and is expressed as:

$\mathrm{G}=\frac{(\ln 2)}{k}$

Therefore, derived from the mathematical adjustment of the powers obtained from the microcalorimetric study of bacterial cultures we can quickly and easily extrapolate the value of the constant growth and the generation time of the bacteria under study (Tables IV-VI).

From the thermogram, we can also calculate the amount of heat $(\mathrm{Q})$ exchanged over the cultivation time.

$Q=K \cdot A$

Where, $(\mu \mathrm{V} \cdot \mathrm{h})$ represents the area, calculated by the trapezoidal method, and $\mathrm{K}$ is a constant that value, $24.8 \mathrm{~J} / \mu \mathrm{V} \cdot \mathrm{h}$, was calculated from the electric calibration performed by the Joule effect on the equipment.

In table VII, we can compare the heat exchanged in different cultures during the first 24 hours. The energy

Table IV

Growth constants $\left(k, k^{\prime}\right)$ and generation time $\left(G, G^{\prime}\right)$ from two phases, for each thermogram of the E. coli

\begin{tabular}{|c|c|c|c|c|c|c|}
\hline \multirow{2}{*}{$\begin{array}{c}\text { Conc. } \\
(\mathrm{CFU} / \mathrm{ml})\end{array}$} & \multicolumn{3}{|c|}{ First phase } & \multicolumn{3}{c|}{ Second phase } \\
\cline { 2 - 7 }$\left(\mathrm{h}^{-1}\right)$ & $\begin{array}{c}G \\
(\mathrm{~h})\end{array}$ & $\mathrm{R}^{2}$ & $\begin{array}{c}K^{\prime} \\
\left(\mathrm{h}^{-1}\right)\end{array}$ & $\begin{array}{c}G^{\prime} \\
(\mathrm{h})\end{array}$ & $\mathrm{R}^{2}$ \\
\hline $10^{6}$ & 1.550 & 0.447 & 0.998 & 0.249 & 2.785 & 0.955 \\
\hline $10^{5}$ & 1.460 & 0.475 & 0.997 & 0.364 & 1.903 & 0.994 \\
\hline $10^{3}$ & 1.770 & 0.392 & 1.000 & 0.291 & 2.384 & 0.992 \\
\hline 10 & 1.685 & 0.413 & 0.995 & 0.141 & 4.913 & 0.986 \\
\hline
\end{tabular}

Table V

Growth constants $\left(k, k^{\prime}\right)$ and generation time $\left(G, G^{\prime}\right)$ from two phases, for each thermogram of the $P$. mirabilis

\begin{tabular}{|l|c|c|c|c|c|c|}
\hline \multirow{2}{*}{$\begin{array}{c}\text { Conc. } \\
(\mathrm{CFU} / \mathrm{ml})\end{array}$} & \multicolumn{3}{|c|}{ First phase } & \multicolumn{3}{c|}{ Second phase } \\
\cline { 2 - 7 }$\left(\mathrm{h}^{-1}\right)$ & $\begin{array}{c}G \\
(\mathrm{~h})\end{array}$ & $\mathrm{R}^{2}$ & $\begin{array}{c}k \\
\left(\mathrm{~h}^{-1}\right)\end{array}$ & $\begin{array}{c}G^{\prime} \\
(\mathrm{h})\end{array}$ & $\mathrm{R}^{2}$ \\
\hline $10^{6}$ & 1.0169 & 0.6816 & 0.9956 & 0.2841 & 2.4398 & 0.9957 \\
\hline $10^{5}$ & 1.2519 & 0.5537 & 0.9947 & 0.298 & 2.3259 & 0.9806 \\
\hline $10^{3}$ & 1.3085 & 0.5297 & 0.9977 & 0.2313 & 2.9967 & 0.9859 \\
\hline 10 & 1.3654 & 0.5076 & 0.9966 & 0.2717 & 2.5511 & 0.9949 \\
\hline
\end{tabular}

Table VI

Growth constants $(k)$ and generation time $(G)$ for each thermogram of the K. pneumoniae

\begin{tabular}{|c|c|c|c|}
\hline $\begin{array}{c}\text { Conc. } \\
(\mathrm{CFU} / \mathrm{ml})\end{array}$ & $\begin{array}{c}k \\
\left(\mathrm{~h}^{-1}\right)\end{array}$ & $\begin{array}{c}G \\
(\mathrm{~h})\end{array}$ & $\mathrm{R}^{2}$ \\
$10^{6}$ & 1.307 & 0.5303 & 0.9954 \\
\hline $10^{5}$ & 1.2818 & 0.5408 & 0.9958 \\
\hline $10^{3}$ & 1.1937 & 0.5807 & 0.9973 \\
\hline 10 & 0.8969 & 0.7728 & 0.9911 \\
\hline
\end{tabular}

Table VIII

$\mathrm{pH}$ values before and after each experiment

\begin{tabular}{|c|c|c|c|c|c|c|}
\hline \multirow{2}{*}{$\begin{array}{c}\text { Conc. } \\
(\mathrm{CFU} / \mathrm{ml})\end{array}$} & \multicolumn{2}{|c|}{ E. coli } & \multicolumn{2}{c|}{ P. mirabilis } & \multicolumn{2}{c|}{ K. pneumoniae } \\
\cline { 2 - 7 } & $\begin{array}{c}\mathrm{pH} \\
\text { initial }\end{array}$ & $\begin{array}{c}\mathrm{pH} \\
\text { final }\end{array}$ & $\begin{array}{c}\mathrm{pH} \\
\text { initial }\end{array}$ & $\begin{array}{c}\mathrm{pH} \\
\text { final }\end{array}$ & $\begin{array}{c}\mathrm{pH} \\
\text { initial }\end{array}$ & $\begin{array}{c}\mathrm{pH} \\
\text { final }\end{array}$ \\
\hline $10^{6}$ & 7.01 & 7.72 & 7.27 & 6.83 & 7.12 & 6.65 \\
\hline $10^{5}$ & 7.07 & 7.67 & 7.12 & 6.86 & 7.18 & 6.67 \\
\hline $10^{3}$ & 7.01 & 7.14 & 7.11 & 6.57 & 7.17 & 6.49 \\
\hline 10 & 7.07 & 7.24 & 7.14 & 6.93 & 7.21 & 6.59 \\
\hline
\end{tabular}

Table VII

Heat $\left(Q_{24}\right)$ produced during culture of E. coli, P. mirabilis and K. pneumoniae over 24 hours

\begin{tabular}{|c|c|c|c|}
\hline $\begin{array}{c}\text { Conc. } \\
(\mathrm{CFU} / \mathrm{ml})\end{array}$ & $\begin{array}{c}\text { E. coli } \\
Q_{24}(\mathrm{~kJ})\end{array}$ & $\begin{array}{c}\text { P. mirabilis } \\
Q_{24}(\mathrm{~kJ})\end{array}$ & $\begin{array}{c}\text { K. pneumoniae } \\
Q_{24}(\mathrm{~kJ})\end{array}$ \\
\hline $10^{6}$ & 13.768 & 23.274 & 35.066 \\
\hline $10^{5}$ & 11.195 & 19.295 & 34.958 \\
\hline $10^{3}$ & 3.452 & 18.989 & 34.456 \\
\hline 10 & 5.113 & 16.534 & 31.783 \\
\hline
\end{tabular}

released is greater as the concentration of the sample increases. Likewise, we should mention that the amount of heat exchanged in cultures of K. pneumoniae, at equal concentrations, is much higher with respect to the other enterobacteria studied.

Metabolism produces waste products. These waste products are usually acidic in nature and produce a decrease in the $\mathrm{pH}$ of the culture medium after the analysis. This was confirmed in samples of $P$. mirabilis and K. pneumoniae. However, in the case of E. coli the $\mathrm{pH}$ increases after cultivation (Table VIII). This difference is probably caused by the ability of E. coli to synthesize a group of proteins as part of the so-called "tolerance response" to acid media when growing in acidic conditions.

\section{Discussion}

Everyone is colonized by more bacterial cells than the number of cells that form part of their bodies. Normally, a symbiotic balance is reached between the bacteria and the host, although at times this balance is broken leading to infection. Despite the broad therapeutic arsenal that we have at our disposal, infectious diseases remain one of the leading causes of death in developed countries. A method of early diagnosis that allows prompt antibiotic treatment, tailored to the antibiotic resistance profile of the causative agent, is crucial.

Microcalorimetry is an analytical technique that measures the heat produced or consumed by chemical reactions or physical changes, including the heat 
exchanged during complex biological processes. It has been used in biology, pharmacology, biotechnology and ecology due to its high sensitivity, precision and simplicity, however, its use in clinical practice has remained highly limited (Trampuz et al., 2007; Baldoni et al., 2009).

Microcalorimetry can determine the presence of microorganisms in a sample within few hours. Even though the initial inoculum contains a low number of bacteria, their exponential replication permits measuring the metabolic heat produced during that process. This information is very important from a clinical point of view. As we can see in the thermograms generated in this work, it is possible to identify the presence of enterobacteria in a sample in less than 8 hours. This is even possible in samples with small initial number of bacteria $(10 \mathrm{CFU} / \mathrm{ml})$.

Based on the tests we performed, we can conclude that in a defined culture medium each species presents a growth profile that is repeated at all the concentrations studied. We thus obtain a "thermal fingerprint" for each bacterial species. The calorimetric curve is defined by a series of electromotive force points recorded by the data acquisition system, and corresponds to the energy exchange that occurs during the culture period. This allows the identification of the bacterial species.

In the thermograms, we record a series of energy peaks that are possibly associated with the ability of each microorganism to assimilate the different components of the culture medium. We should highlight the similarities between the thermograms of E. coli and P. mirabilis two species that have mixed-acid glucose fermentation. K. pneumoniae is characterized by its butanodiol fermentation and shows radically different thermograms.

The results were analyzed in a way to allow us to quickly and easily calculate the value of the growth constant $(\mathrm{K})$, and the generation time $(\mathrm{G})$. These parameters are characteristic of each bacterial species. Calculating these parameters by the usual methods required is difficult and requires a lot of work. In addition, microcalorimetry allows us to quantify the amount of heat exchanged $(\mathrm{Q})$ in a bacterial culture over a defined period. Known dynamic parameters allow new, extended studies on the behaviour of a bacterial species in the presence of various substances, for example antibiotics. These will contribut to the understanding of the antibiotic resistance and to the analysis of different treatment options.

Microcalorimetry has proven to be a useful and efficient technique in the early detection of enterobacteria in a culture medium. It allows to detect and quantify very small amounts of energy exchanged, and consequently to detect bacterial growth. The method is usable even with very small inoculum such as $10 \mathrm{CFU} / \mathrm{ml}$.
The calorimetric curves obtained allow us to qualitatively characterize the enterobacteria studied. This makes it possible to identify the species in the first 24 hours of cultivation. Therefore, microcalorimetry is a technique that could determine the causative agent of infection in less than 24 hours. It could speed up diagnosis and initiation of the appropriate treatment.

\section{Acknowledgments}

We thank María Perfecta Salgado González and Sofia Baz Rodríguez for their collaboration with the technical measures.

\section{Literature}

Baldoni D., H. Hermann, R. Frei, A. Trampuz and A. Steinhuber. 2009. Performance of Microcalorimetry for Early Detection of Methicillin Resistance in Clinical Isolates of Staphylococcus aureus. J. Clin Microbiol. 47: 774-776.

Calvet E. and H. Prat. 1956. Microcalorimétrie: Aplications physico-chimiques et biologiques. Masson el $\mathrm{C}^{\mathrm{ie}}$ Editeurs, Paris.

James A.M. 1987. Calorimetry. Past, Present and Future. In thermal and energetic studies of cellular biological systems. Bristol, UK: IOP Publishing Ltd.

Kenneth, J., C. Ryan and R. George. 2004. Microbiología médica. Una introducción a las enfermedades infecciosas. McGraw Hill.

Lago N., J.L. Legido, I. Arias and F. García. 2010a. Aplicaciones de la microcalorimetría como método de identificación precoz del crecimiento bacteriano. Investigación, cultura, ciencia y tecnología. 2: 6-9.

Lago N., J.L. Legido, M.I. Paz-Andrade, I. Arias and L.M. Casás. 2010b. Microcalorimetric study on the growth and metabolismo of Pseudomonas aeruginosa. J. Therm. Anal. Calorim. 105 (2011): 651-655.

Liang H., J. Wu, Y. Liu, L. Yang, L. Hu and S. Qu. 2003. Kinetics of the Action of Three Selenides on Staphylococcus aureus Growth as Studied by Microcalorimetry. Biol. Trace. Elem. Res. 92: 181-187. Ma J., W.T. Qi, L.N. Yang, W.T. Yu, Y.B. Xie and W. Wang. 2007. Microcalorimetric study on the growth and metabolism of microencapsulated microbial cell culture. Journal for Microbiological Methods. 68, 172-177.

Murray P., K. Rosentha and M. Pfaller. 2009. Microbiología médica. Elsevier Mosby.

O’Neill M., G. Vine, A. Beezer, A. Bishop, J. Hadgraft and C.H. Labetoulle. 2003. Antimicrobial properties of silver-containing wound dressings: a microcalorimetric study. Int. J. Pharm. 263: 61-68.

Paz Andrade M.I. 1967. Les Dévelopements Récents de la Microcalorimétrie et de la Thermogenese, $1^{\text {st }}$ Ed. Paris: CRNS.

Trampuz A., S. Salzmann, J. Antheaaume and A.U. Daniela. 2007. Microcalorymetry: a novel method for detedtion of microbial contamination inplatelet products. Transfusión. 47: 1643-1650.

Wang X., Y. Liu, B. Xie, X. Shi, J. Zhou and H. Zhang. 2005. Effects of nisin on the grow of Staphylococcus aureus determined by a microcalorimetric method. Mol. Nutr. Food Res. 49: 350-354.

Xu X.J., C. Chen, Z. Wang, Y. Zhang, A. Hou and C. Li. 2008. Antibacterial Activities of Novel Diselenide-bridged bis(Porphyrin) $\mathrm{s}$ on Staphylococcus aureus Investigated by Microcalorimetry. Biol Trance Elem Res. 125: 185-192.

Yang L.N., L. Xian, F. Xu, J. Zhang, J.N. Zhao and Z.B. Zhao. 2010. Inhibitory study of two cephalosporins on $E$. coli by microcalorimetry. J. Therm. Anal. Calorim.100, 589-592. 